\title{
Profil lipid wanita menopause di Panti Werdha Damai Manado
}

\author{
${ }^{1}$ Prisilia D. D. Sumoked \\ ${ }^{2}$ Hermie M. M Tendean \\ ${ }^{2}$ Eddy Suparman
}

\author{
${ }^{1}$ Kandidat Skripsi Fakultas Kedokteran Universitas Sam Ratulangi Manado \\ ${ }^{2}$ Bagian Obstetri dan Ginekologi Fakultas Kedokteran Universitas Sam Ratulangi \\ RSUP Prof. Dr. R.D. Kandou Manado \\ Email: prisiliasumoked@yahoo.com
}

\begin{abstract}
In Indonesia, women over the age of 50 years that will become menopause in 2020 are estimated as many as 30.3 million people. A decline in estrogen level at menopause will affect the functions of the female reproductive system as well as of the other body systems, including lipid metabolism. This study was aimed to determine the lipid profile of menopausal women at Panti Werdha Damai (senior housing) Manado. This was a descriptive, prospective, and observational study with a cross sectional design. There were 30 menopausal women obtained by using purposive sampling method. Lipid profile was examined at Prodia Laboratorium Manado. Data were analyzed by using SPSS 20 . The results showed that most respondents $(86.7 \%)$ were $\geq 65$ years old. There were 21 women $(70 \%)$ with total cholesterol level $\geq 200 \mathrm{mg} / \mathrm{dl}$ (mean value of $211.2 \mathrm{mg} / \mathrm{dl}$ ); 27 women (90\%) with LDL-cholesterol level $\geq 100 \mathrm{mg} / \mathrm{dl}$ (mean value of $137.8 \mathrm{mg} / \mathrm{dl}$ ); 25 women (83.3\%) with HDL cholesterol $\geq 40 \mathrm{mg} / \mathrm{dl}$ (mean value of $50.9 \mathrm{mg} / \mathrm{dl}$ ); and 26 women $(87.7 \%$ ) with triglyceride level $\leq 150 \mathrm{mg} / \mathrm{dl}$ (mean value of $111.4 \mathrm{mg} / \mathrm{dl}$ ). Conclusion: Most of the menopausal women at Panti Werdha Damai Manado were at the age of $\geq 65$ years. The average values of total and LDL cholesterol were above the reference value, meanwhile the average values of HDL cholesterol and triglycerides were within normal limit.
\end{abstract}

Keywords: menopausal women, lipid profile.

\begin{abstract}
Abstrak: Di Indonesia perempuan yang berusia lebih dari 50 tahun telah memasuki menopause pada tahun 2020 diperkirakan sebanyak 30,3 juta orang. Saat menopause terjadi penurunan estrogen yang tidak hanya memengaruhi fungsi sistem reproduksi wanita, tetapi juga terhadap sistem tubuh lainnya antara lain metabolisme lipid. Penelitian ini bertujuan untuk mengetahui profil lipid wanita menopause di Panti Werdha Damai Manado. Jenis penelitian ialah observasional serta deskriptif prospektif dengan desain potong lintang. Didapatkan 30 wanita menopause dengan menggunakan metode purposive sampling dan dilakukan pemeriksaan profil lipid di Laboratorium Prodia Manado. Data dianalisis menggunakan SPSS 20. Hasil penelitian memperlihatkan bahwa sebagian besar responden $(86,7 \%)$ berusia $\geq 65$ tahun. Kadar kolesterol total terbanyak ialah $\geq 200 \mathrm{mg} / \mathrm{dl}$ berjumlah 21 orang $(70 \%)$ dengan nilai rerata $211,2 \mathrm{mg} / \mathrm{dl}$. Kadar kolesterol LDL terbanyak ialah $\geq 100$ $\mathrm{mg} / \mathrm{dl}$ pada 27 orang $(90 \%)$, nilai rerata $137,8 \mathrm{mg} / \mathrm{dl}$. Kadar kolesterol HDL terbanyak ialah $\geq 40 \mathrm{mg} / \mathrm{dl}$ pada 25 orang $(83,3 \%)$, nilai rerata $50,9 \mathrm{mg} / \mathrm{dl}$. Kadar trigliserida terbanyak ialah $<150 \mathrm{mg} / \mathrm{dl}$ pada 26 orang $(86,7 \%)$, nilai rerata $111,4 \mathrm{mg} / \mathrm{dl}$. Simpulan: Sebagian besar wanita menopause di Panti Werdha Damai Manado berusia $\geq 65$ tahun dengan nilai rerata kolesterol total dan kolesterol LDL berada di atas nilai rujukan sedangkan nilai rerata kolesterol HDL dan trigliserida sesuai nilai rujukan.
\end{abstract}

Kata kunci: wanita menopause, profil lipid 
Peningkatan pertumbuhan penduduk yang sangat cepat merupakan salah satu karakteristik kependudukan di abad $21{ }^{1}$ Menurut data dari WHO, pada tahun 2000 total populasi wanita yang mengalami menopause di seluruh dunia mencapai 645 juta orang, tahun 2010 mencapai 894 juta orang, dan diperkirakan nantinya di tahun 2030 jumlah perempuan di dunia yang memasuki masa menopause akan mencapai 1,2 milyar orang. ${ }^{2}$ Di Indonesia wanita yang berusia lebih dari 50 tahun telah memasuki menopause sebanyak 15,5 juta pada tahun 2000, diperkirakan pada tahun 2020 perempuan yang usianya lebih dari 50 tahun telah memasuki menopause sebanyak 30,3 juta, dan berdasarkan perkiraan Badan Pusat Statistik (BPS) pada tahun 2025, ada 60 juta wanita menopause di Indonesia. Bertambahnya populasi wanita berusia lebih dari 50 tahun menunjukkan bahwa dalam kehidupan semakin banyak wanita yang akan melewati fase menopause sehingga perlu dipikirkan untuk bisa melalui kehidupan yang bermakna dan berkualitas. Peningkatan kelompok lanjut usia secara demografi akan menjadi masalah kesehatan masyarakat yang memerlukan penanganan khusus. ${ }^{1,2}$

Menopause ialah hal yang fisiologik bagi wanita. Wanita dikatakan mengalami menopause bila tidak menstruasi atau mengalami amenorea sekurang-kurangnya selama satu tahun. ${ }^{3}$ Rerata usia untuk menopause 51,3 tahun. ${ }^{4}$ Di Indonesia, perkiraan rerata usia menopause 50-52 tahun. $^{2}$

Penurunan drastis estrogen ovarium pada menopause memengaruhi sistem kardiovaskular karena estrogen memiliki efek fisiologik yang luas di luar sistem reproduksi. ${ }^{5}$ Hormon estrogen terdiri dari estriol, estron dan estradiol. Yang mempunyai potensi estrogenik paling kuat dan merupakan bagian terbesar dari estrogen ialah estradiol. Berkurang sampai hilangnya hormon estradiol akibat hilangnya fungsi ovarium dapat menyebabkan penurunan fungsi alat tubuh dan gangguan penurunan metabolisme, seperti metabolisme lipid. ${ }^{6}$ Selain itu, estrogen juga dapat mencegah terjadinya pengendapan di pembuluh darah dengan menaikkan kadar kolesterol high-density lipoprotein (HDL) dan menurunkan kadar kolesterol lowdensity lipoprotein (LDL). ${ }^{7}$ Pada saat mulai menopause, terjadi peningkatan kejadian dislipidemia. $^{8}$ Berdasarkan penelitian Swapnali et al. ${ }^{9}$ pada wanita menopause di India, nilai rerata kolesterol total, trigliserida, dan kolesterol LDL meningkat kecuali kolesterol HDL yang menurun bila dibandingkan dengan wanita premenopause yang secara statistik sangat signifikan. Penelitian oleh Khairani dan Sumiera ${ }^{10}$ tentang profil lipid pada penduduk lanjut usia di Jakarta mendapatkan hasil lansia wanita memiliki kadar kolesterol total $\geq 240$ $\mathrm{mg} / \mathrm{dl}$, kolesterol LDL $\geq 160 \mathrm{mg} / \mathrm{dl}$ dan trigliserida $\geq 200 \mathrm{mg} / \mathrm{dl}$ lebih banyak dibandingkan pria. ${ }^{10}$ Bila terjadi kelainan fraksi lipid seperti kenaikan kolesterol LDL, kenaikan trigliserida, kenaikan kolesterol total dan penurunan kolesterol HDL maka risiko terjadinya kelainan vaskular meningkat. $^{7}$

\section{METODE PENELITIAN}

Jenis penelitian yang digunakan ialah observasional deskriptif prospektif dengan desain potong lintang. Didapatkan 30 wanita menopause sebagai sampel yang memenuhi kriteria inklusi, yaitu wanita yang sudah berhenti haid secara permanen minimal selama 12 bulan berturut-turut, tidak diberikan terapi hormonal selama 6 bulan, tidak mengonsumsi obat yang memengaruhi profil lipid, tidak menderita DM, tidak merokok, dan IMT $<25 \mathrm{~kg} / \mathrm{m}^{2}$. Pengambilan sampel dilakukan dengan cara purposive sampling dan dilakukan pengambilan darah sebanyak $5 \mathrm{ml}$ kemudian diproses di Laboratorium Klinik Prodia Manado untuk mendapatkan hasil profil lipid. Penelitian ini dilakukan pada bulan November-Desember 2015. Hasil penelitian dianalisis menggunakan SPSS 20.

\section{HASIL PENELITIAN}

Pada Tabel 1, berdasarkan usia sampel terbanyak berada pada usia $\geq 65$ tahun berjumlah 26 orang $(86,7 \%)$. Berdasarkan 
IMT, sampel terbanyak berada pada IMT antara 18,5-24,9 berjumlah 26 orang $(86,7 \%)$. Berdasarkan tekanan darah, sampel terbanyak berada pada kategori normotensi berjumlah 17 orang $(56,7 \%)$.

Tabel 1. Karakteristik wanita menopause

\begin{tabular}{lcc}
\hline Karakteristik & n & \% \\
\hline Usia (tahun) & & \\
$\quad<65$ & 4 & 13,3 \\
$\quad>65$ & 26 & 86,7 \\
Jumlah & 30 & 100 \\
\hline IMT & & \\
$\quad<18,5$ & 4 & 13,3 \\
$\quad 18,5-24,9$ & 26 & 86,7 \\
Jumlah & 30 & 100.0 \\
\hline Tekanan darah & & \\
$\quad$ Normotensi & 17 & 56,7 \\
$\quad$ Hipertensi & 13 & 43,3 \\
Jumlah & 30 & 100 \\
\hline
\end{tabular}

Tabel 2 memperlihatkan kadar kolesterol total terbanyak $\geq 200 \mathrm{mg} / \mathrm{dl}$ berjumlah 21 orang (70\%). Kadar kolesterol LDL terbanyak $\geq 100 \mathrm{mg} / \mathrm{dl}$ berjumlah 27 orang (90\%). Kadar kolesterol HDL terbanyak $\geq 40$ $\mathrm{mg} / \mathrm{dl}$ berjumlah 25 orang $(83,3 \%)$. Kadar trigliserida terbanyak $<150 \mathrm{mg} / \mathrm{dl}$ berjumlah 26 orang $(86,7 \%)$.

Tabel 2. Profil lipid plasma wanita menopause

\begin{tabular}{lcc}
\hline Profil Lipid & n & \% \\
\hline Kolesterol Total (mg/dl) & & \\
$<200$ & 9 & 30 \\
$\geq 200$ & 21 & 70 \\
Jumlah & 30 & 100 \\
\hline Kolesterol LDL (mg/dl) & & \\
$<100$ & 3 & 10 \\
$\geq 100$ & 27 & 90 \\
Jumlah & 30 & 100 \\
\hline Kolesterol HDL (mg/dl) & & \\
$<40$ & 5 & 16,7 \\
$\geq 40$ & 25 & 83,3 \\
Jumlah & 30 & 100 \\
\hline Trigliserida (mg/dl) & & \\
$<150$ & 26 & 86,7 \\
$\geq 150$ & 4 & 13,3 \\
Jumlah & 30 & 100 \\
\hline & & \\
\hline
\end{tabular}

Tabel 3 memperlihatkan kolesterol total memiliki nilai rerata, nilai minimum dan maksimum berturut-turut $211,2 \mathrm{mg} / \mathrm{dl}$, $121 \mathrm{mg} / \mathrm{dl}, 320 \mathrm{mg} / \mathrm{dl}$. Kolesterol LDL memiliki nilai rerata, nilai minimum dan maksimum berturut-turut $137,8 \mathrm{mg} / \mathrm{dl}, 58$ $\mathrm{mg} / \mathrm{dl}, \quad 243 \mathrm{mg} / \mathrm{dl}$. Kolesterol HDL memiliki nilai rerata, nilai minimum dan maksimum berturut-turut 50,9 mg/dl, 33 $\mathrm{mg} / \mathrm{dl}, 95 \mathrm{mg} / \mathrm{dl}$. Trigliserida memiliki nilai rerata, nilai minimum dan maksimum berturut-turut 111,4 mg/dl, $44 \mathrm{mg} / \mathrm{dl}, 223$ $\mathrm{mg} / \mathrm{dl}$.

Tabel 3. Nilai rerata, nilai minimum dan nilai maksimum profil lipid plasma wanita menopause

\begin{tabular}{|c|c|c|c|}
\hline Profil lipid & $\begin{array}{c}\text { Nilai } \\
\text { rerata } \\
(\mathrm{mg} / \mathrm{dl})\end{array}$ & $\begin{array}{c}\text { Nilai } \\
\text { minimum } \\
(\mathrm{mg} / \mathrm{dl})\end{array}$ & $\begin{array}{c}\text { Nilai } \\
\text { maksimum } \\
(\mathrm{mg} / \mathrm{dl})\end{array}$ \\
\hline \multicolumn{4}{|l|}{ Kolesterol } \\
\hline \multicolumn{4}{|l|}{ Total (mg/dl) } \\
\hline \multicolumn{4}{|l|}{$<200$} \\
\hline$\geq 200$ & 211,2 & 121 & 320 \\
\hline \multicolumn{4}{|l|}{ Kolesterol } \\
\hline \multicolumn{4}{|l|}{$\mathrm{LDL}(\mathrm{mg} / \mathrm{dl})$} \\
\hline$<100$ & 137,8 & 58 & 243 \\
\hline \multicolumn{4}{|l|}{$\geq 100$} \\
\hline \multicolumn{4}{|l|}{ Kolesterol } \\
\hline$<40$ & 50,9 & 33 & 95 \\
\hline \multicolumn{4}{|l|}{$\geq 40$} \\
\hline \multicolumn{4}{|l|}{$\begin{array}{l}\text { Trigliserida } \\
\text { (mg/dl) }\end{array}$} \\
\hline$<150$ & 111,4 & 44 & 223 \\
\hline$\geq 150$ & & & \\
\hline
\end{tabular}

Tabel 4 memperihatkan profil lipid terbanyak berdasarkan umur berada pada umur $\geq 65$ tahun. Berdasarkan IMT, profil lipid terbanyak berada pada IMT 18,5-24,9. Berdasarkan tekanan darah, profil lipid terbanyak berada pada kategori normotensi. Berdasarkan umur, IMT dan tekanan darah paling banyak berada pada kadar kolesterol total $\geq 200 \mathrm{mg} / \mathrm{dl}$, kolesterol LDL $\geq 100$ $\mathrm{mg} / \mathrm{dl}$, kolesterol HDL $\geq 40 \mathrm{mg} / \mathrm{dl}$, dan trigliserida $<150 \mathrm{mg} / \mathrm{dl}$.

\section{BAHASAN}

Menopause adalah fase dari proses penuaan dimana wanita melewati masa reproduksi menuju non reproduksi. ${ }^{11}$ Tidak seperti keadaan kekurangan hormon lainnya, menopause bukan merupakan 
suatu penyakit. ${ }^{12}$ Menurunnya estrogen selama dan setelah menopause menyebabkan terjadinya perubahan struktural, fisiologis dan biokimia yang mengubah kesehatan wanita secara umum. Perubahan hormonal yang berhubungan dengan menopause memberikan efek yang signifikan pada metabolisme lipid plasma dan lipoprotein. ${ }^{11,13}$

Tabel 1 menunjukkan karakteristik wanita menopause berdasarkan usia, IMT, dan tekanan darah. Wanita berusia $<65$ tahun berjumlah 4 orang $(13,3 \%)$ dan $\geq 65$ tahun berjumlah 26 orang $(86,7 \%)$. Berdasarkan IMT $<18,5$ berjumlah 4 orang (13,3\%) dan IMT 18,5-24,9 berjumlah 26 orang $(86,7 \%)$. Berdasarkan tekanan darah, yang tergolong normotensi berjumlah 17 orang $(56,7 \%)$ dan tergolong hipertensi berjumlah 13 orang $(43,3 \%)$.

Tabel 2 menunjukkan bahwa dari 30 sampel terdapat 21 orang $(70 \%)$ yang memiliki kadar kolesterol total $\geq 200 \mathrm{mg} / \mathrm{dl}$. Studi di beberapa pusat di negara berkembang menunjukkan nilai yang lebih tinggi dengan dislipidemia ialah kolesterol $>240 \mathrm{mg} \%$ (6.21 mmol/l) dan terjadi pada 25-33\% wanita. ${ }^{14}$ Pada penelitian Swapnali et al. ${ }^{9}$ didapatkan kadar kolesterol total yang meningkat pada wanita pascamenopause oleh karena kekurangan estrogen bila dibandingkan dengan wanita pramenopause dan bermakna secara statistik. Penelitian Kim CJ et al. ${ }^{15}$ menunjukkan kadar kolesterol total meningkat secara bertahap dari wanita pramenopause menuju pascamenopause.

Tabel 4. Profil lipid plasma berdasarkan karakteristik usia, indeks massa tubuh (IMT) dan tekanan darah

\begin{tabular}{|c|c|c|c|c|c|c|c|c|c|c|c|c|c|c|c|c|}
\hline \multirow{4}{*}{ Karakteristik } & \multicolumn{16}{|c|}{$\begin{array}{c}\text { Profil Lipid } \\
\end{array}$} \\
\hline & \multicolumn{4}{|c|}{$\begin{array}{c}\text { Kolesterol Total } \\
(\mathrm{mg} / \mathrm{dl})\end{array}$} & \multicolumn{4}{|c|}{$\begin{array}{l}\text { Kolesterol LDL } \\
\text { (mg/dl) }\end{array}$} & \multicolumn{4}{|c|}{$\begin{array}{c}\text { Kolesterol HDL } \\
\text { (mg/dl) }\end{array}$} & \multicolumn{4}{|c|}{$\begin{array}{c}\text { Trigliserida } \\
\text { (mg/dl) }\end{array}$} \\
\hline & \multicolumn{2}{|c|}{$<200$} & \multicolumn{2}{|c|}{$\geq 200$} & \multicolumn{2}{|c|}{$<100$} & \multicolumn{2}{|c|}{$\geq 100$} & \multicolumn{2}{|c|}{$<40$} & \multicolumn{2}{|c|}{$\geq 40$} & \multicolumn{2}{|c|}{$<150$} & \multicolumn{2}{|c|}{$\geq \mathbf{1 5 0}$} \\
\hline & n & $\%$ & n & $\%$ & $\mathbf{n}$ & $\%$ & n & $\%$ & $\mathbf{n}$ & $\%$ & $\mathbf{n}$ & $\%$ & $\mathbf{n}$ & $\%$ & $\mathbf{n}$ & $\%$ \\
\hline \multicolumn{17}{|l|}{ Usi (tahun) } \\
\hline$<65$ & 2 & 6,7 & 2 & 6,7 & - & - & 4 & 13,3 & - & - & 4 & 13,3 & 4 & 13,3 & - & - \\
\hline$\geq 65$ & 7 & 23 & 19 & 63,3 & 3 & 10 & 23 & 76,7 & 5 & 16,7 & 21 & 70 & 22 & 73,3 & 4 & 13,3 \\
\hline \multicolumn{17}{|l|}{ IMT } \\
\hline$<18,5$ & 2 & 6,7 & 2 & 6,7 & - & - & 4 & 13,3 & 1 & 3,3 & 3 & 10 & 4 & 13,3 & - & - \\
\hline $18,5-24,9$ & 7 & 23 & 19 & 63,3 & 3 & 10 & 23 & 76,7 & 4 & 13,3 & 22 & 73,3 & 22 & 73,3 & 4 & 13,3 \\
\hline \multicolumn{17}{|l|}{$\mathrm{TD}$} \\
\hline Normotensi & 6 & 20 & 11 & 36,7 & 2 & 6,7 & 15 & 50 & 3 & 10 & 14 & 46,7 & 15 & 50 & 2 & 6,7 \\
\hline Hipertensi & 3 & 10 & 10 & 33,3 & 1 & 3,3 & 12 & 40 & 2 & 6,7 & 11 & 36,7 & 11 & 36,7 & 2 & 6,7 \\
\hline
\end{tabular}

Keterangan: $\mathrm{K}=$ Kolesterol, $\mathrm{n}=$ jumlah, IMT=Indeks Massa Tubuh, $\mathrm{TD}=$ tekanan darah

Pada penelitian ini juga terdapat 27 orang (90\%) yang memiliki kadar kolesterol LDL $\geq 100 \mathrm{mg} / \mathrm{dl}$. Kulkarni et al. $^{16}$ dalam penelitiannya mendapatkan hasil yang menunjukkan kadar kolesterol LDL meningkat secara bermakna pada wanita menopause bila dibandingkan dengan wanita pramenopause.

Kadar kolesterol HDL $<40 \mathrm{mg} / \mathrm{dl}$ yang didapatkan berjumlah 5 orang $(16,7 \%)$ dari 30 sampel wanita menopause yang memenuhi kriteria inklusi. Hal ini menunjukkan bahwa terdapat 25 orang $(83,3 \%)$ yang memiliki kadar kolesterol HDL sesuai dengan nilai rujukan. Pada penelitian Kulkarni et al. ${ }^{16}$ didapatkan kadar kolesterol HDL tidak meningkat dan secara statistik tidak bermakna, namun kadar kolesterol HDL sedikit lebih tinggi pada wanita pramenopause dibandingkan wanita pascamenopause. Hal ini berbeda dengan hasil penelitian Mesalic et al. $^{17}$ yang menunjukkan kadar kolesterol HDL pada wanita menopause secara bermakna 
lebih rendah dibandingkan wanita dengan menstruasi teratur. Selain itu, penelitian Swapnali et al. ${ }^{9}$ menunjukkan kadar kolesterol HDL yang tinggi pada wanita pramenopause dibandingkan wanita pascamenopause dan bermakna secara statistik.

Untuk kadar trigliserida, pada penelitian ini didapatkan 4 orang dengan kadar trigliserida di atas nilai rujukan. Hal ini menunjukkan bahwa sebagian besar sampel dengan jumlah 26 orang $(86,7 \%)$ memiliki kadar trigliserida yang sesuai nilai rujukan. Penelitian Mesalic et al. ${ }^{17}$ menunjukkan bahwa konsentrasi trigliserida pada wanita menopause tidak mengalami peningkatan secara bermakna.

Pada Tabel 3 didapatkan nilai rerata kolesterol total $211,2 \mathrm{mg} / \mathrm{dl}$ dan kolesterol LDL $137,8 \mathrm{mg} / \mathrm{dl}$ meningkat di atas nilai rujukan. Selain itu, nilai rerata kolesterol HDL 50,9 mg/dl dan trigliserida 111,4 $\mathrm{mg} / \mathrm{dl}$ sesuai dengan nilai rujukan. Hasil profil lipid wanita menopause ini dilaporkan pernah diteliti pada tahun 2001 oleh Widyayati ${ }^{6}$ yang menunjukkan nilai rerata kolesterol total dan kolesterol LDL meningkat di atas nilai rujukan sementara nilai rerata kolesterol HDL dan trigliserida berada pada nilai rujukan. Namun penelitian yang dilakukan Widyayati menggunakan nilai rujukan yang berbeda dengan nilai rujukan yang ada pada penelitian ini. Widyayati yenggunakan rujukan kolesterol total $<200 \mathrm{mg} / \mathrm{dl}$, kolesterol LDL $<130 \mathrm{mg} / \mathrm{dl}$, kolesterol HDL $\geq 35 \mathrm{mg} / \mathrm{dl}$ dan trigliserida $<200$ $\mathrm{mg} / \mathrm{dl}$ sedangkan pada penelitian ini penulis mengambil nilai rujukan kolesterol total $<200 \mathrm{mg} / \mathrm{dl}$, kolesterol LDL <100 mg/dl, kolesterol HDL $\geq 40 \mathrm{mg} / \mathrm{dl}$, dan trigliserida $<150 \mathrm{mg} / \mathrm{dl}$ berdasarkan nilai rujukan dari Laboratorium Klinik Prodia Manado dan nilai optimal dari National Cholesterol Education Program Adult Treatment Panel III (NCEP ATP III) 2001.

Pada penelitian Swapnali et al. ${ }^{9}$ didapatkan peningkatan rerata nilai kolesterol total, kolesterol LDL, trigliserida dan penurunan rerata nilai kolesterol HDL pada wanita pascamenopause dibandingkan dengan wanita pramenopause. Berbeda dengan hasil penelitian yang dilakukan oleh penulis, didapatkan nilai rerata kolesterol total dan kolesterol LDL di atas nilai rujukan sedangkan kolesterol HDL dan trigliserida sesuai dengan nilai rujukan. Perbedaan ini terjadi mungkin karena penelitian Swapnali et al menggunakan subjek pembanding yaitu antara wanita pramenopause dengan wanita pascamenopause sedangkan penelitian yang dilakukan penulis tidak menggunakan subjek pembanding untuk mengetahui terjadinya peningkatan ataupun penurunan profil lipid. Selain itu, pada penelitian ini didapatkan nilai rerata kolesterol HDL dan trigliserida yang sesuai dengan nilai rujukan mungkin disebabkan oleh karena berbagai faktor, salah satunya yaitu masih terdapat cadangan estrogen yang dimiliki wanita menopause karena wanita pascamenopause masih terus menghasilkan hingga $20 \mathrm{mg}$ estrogen per hari lewat jaringan lemak, hati dan korteks adrenal. ${ }^{5}$

Diketahui perubahan pada lipid yang terjadi memiliki hubungan dengan usia dan transisi menopause. ${ }^{18}$ Hasil penelitian pada tabel 4 menyatakan kadar kolesterol total, kolesterol LDL, kolesterol HDL, dan trigliserida berdasarkan umur, terbanyak pada umur $\geq 65$ tahun dengan kadar kolesterol total terbanyak $\geq 200 \mathrm{mg} / \mathrm{dl}$ berjumlah 19 orang $(63,3 \%)$, kadar kolesterol LDL terbanyak $\geq 100 \mathrm{mg} / \mathrm{dl}$ berjumlah 23 orang $(76,7 \%)$, kadar kolesterol HDL terbanyak $\geq 40 \mathrm{mg} / \mathrm{dl}$ berjumlah 21 orang $(70 \%)$ serta kadar trigliserida terbanyak $<150 \mathrm{mg} / \mathrm{dl}$ berjumlah 22 orang (73,3\%). Sedangkan berdasarkan IMT, kadar kolesterol total, kolesterol LDL, kolesterol HDL, dan trigliserida terbanyak berada pada IMT 18,5-24,9 dengan kadar kolesterol total terbanyak $\geq 200 \mathrm{mg} / \mathrm{dl}$, kadar kolesterol LDL terbanyak $\geq 100 \mathrm{mg} / \mathrm{dl}$, kadar trigliserida terbanyak $<150 \mathrm{mg} / \mathrm{dl}$ dengan jumlah dan persentase yang sama dengan umur $\geq 65$ tahun serta kadar kolesterol HDL terbanyak $\geq 40 \mathrm{mg} / \mathrm{dl}$ berjumlah 22 orang $(73,3 \%)$. Berdasarkan tekanan darah, kadar kolesterol total, kolesterol LDL, kolesterol HDL, dan trigliserida terbanyak berada pada kategori normotensi dengan kadar kolesterol total 
terbanyak $\geq 200 \mathrm{mg} / \mathrm{dl}$ berjumlah 11 orang $(36,7 \%)$, kadar kolesterol LDL terbanyak $\geq 100 \mathrm{mg} / \mathrm{dl}$ berjumlah 15 orang (50\%), kadar kolesterol HDL terbanyak $\geq 40 \mathrm{mg} / \mathrm{dl}$ berjumlah 14 orang $(46,7 \%)$ dan kadar trigliserida terbanyak $<150 \mathrm{mg} / \mathrm{dl}$ berjumlah 15 orang $(50 \%)$.

Penelitian oleh Bade et al. ${ }^{12}$ mendapatkan bahwa terjadinya perubahan kadar lipid bukan karena perbedaan IMT, tetapi karena perbedaan status hormonal pada wanita. Peningkatan tekanan darah saat menopause mungkin merupakan konsekuensi dari penuaan daripada perubahan status hormonal. Kelebihan berat badan dan kelebihan lemak perut memiliki korelasi positif dengan peningkatan tekanan darah. ${ }^{19}$ Telah terbukti secara konsisten bahwa menopause menyebabkan peningkatan serum kolesterol, namun efek dari perimenopause dan pascamenopause pada tekanan darah tetap tidak jelas. ${ }^{20}$

Estrogen memberikan aksi kardioprotektif dengan mempertahankan kadar kolesterol HDL dan menurunkan kolesterol LDL serta trigliserida. Hilangnya perlindungan setelah terjadi menopause bertanggung jawab terhadap peningkatan risiko penyakit kardiovaskular pada wanita pascamenopause. $^{11}$ Selain itu juga, menurunnya tingkat aktifitas fisik memiliki peran yang sangat penting dalam perubahan profil lipid selama periode pasca menopause. Asam lemak bebas merupakan sumber energi utama selama olahraga. Untuk memobilisasi energi yang tersimpan dalam jaringan adiposa untuk digunakan selama aktifitas fisik, trigliserida yang dihidrolisis disimpan untuk membentuk asam lemak bebas dan gliserol. Konversi ini dikatalisis oleh enzim yaitu lipase trigliserida sensitif hormon (hormone sensitive trigliserid lipase). Olahraga juga meningkatkan aktivitas enzim lipoprotein lipase lapisan endotelium kapiler. Dengan demikian, olahraga dapat menurunkan kadar kolesterol total, trigliserida, dan VLDL sementara pengurangan aktivitas fisik selama periode pascamenopause dapat meningkatkan kadar tersebut. Olahraga juga membantu meningkatkan kadar kolesterol HDL pada wanita pascamenopause dan mengurangi kadar lipid lainnya sedangkan korteks adrenal dan gonad sangat aktif pada degradasi LDL. ${ }^{12}$ Berbagai studi menunjukkan bahwa sirkulasi lipid dan lipoprotein dipengaruhi oleh hormon gonad. ${ }^{21}$ Menurunnya aktivitas gonad selama menopause dapat meningkatkan kadar LDL. ${ }^{12}$

\section{SIMPULAN}

Dari hasil penelitian terhadap 30 wanita menopause di Panti Werdha Damai Manado dapat disimpulkan bahwa:

1. Jumlah terbanyak berada pada usia 65 tahun ke atas.

2. Nilai rerata kolesterol total dan kolesterol LDL berada di atas nilai rujukan sedangkan nilai rerata kolesterol HDL dan trigliserida sesuai nilai rujukan.

\section{SARAN}

1. Melakukan pemeriksaan profil lipid, mengontrol asupan makanan, aktifitas fisik dan berat badan pada wanita yang sudah mengalami menopause.

2. Mendapatkan pengobatan bila kolesterol total, kolesterol LDL, kolesterol HDL, dan trigliserida tidak berada pada nilai optimal (tidak sesuai nilai rujukan).

3. Penelitian ini dapat dikembangkan dengan menghitung indeks aterogenik untuk mengetahui besar potensi terjadinya aterosklerosis pada wanita menopause.

\section{UCAPAN TERIMA KASIH}

Ucapan terima kasih disampaikan kepada dr. Jefferson Rompas, SpOG, dr. Linda M. Mamengko, $\operatorname{SpOG}(\mathrm{K})$ serta semua pihak yang baik secara langsung maupun tidak langsung telah menumbuhkan ide atau gagasan dalam pemikiran penulis sehingga dapat menyelesaikan artikel ini. 
DAFTAR PUSTAKA

1. Ghani L. Seluk beluk menopause. Media Penelitian dan Pengembangan Kesehatan. 2009;19:193-7.

2. Mawaddah M. Determinan kecemasan wanita pra menopause di desa Rawang Lama Kecamatan Rawang Panca Arga kabupaten Asahan tahun 2014 [Tesis]. Medan: Fakultas Kesehatan Masyarakat Universitas Sumatera Utara; 2014.

3. Pradana A. Hubungan jumlah paritas dengan usia menopause [Skripsi]. Medan: Fakultas Kedokteran Universitas Sumatera Utara; 2010.

4. Speroff L, Fritz MA. Clinical gynecologic endocrinology and infertility (7th ed). Philadelphia: Lippincott Williams \& Wilkins, 2005; p. 621-88.

5. Sherwood L. Fisiologi manusia: dari sel ke sistem (8th ed). Jakarta: EGC, 2014; p. 781-841.

6. Widyayati STK. Hubungan antara kadar estrogen dengan profil lipid pada wanita menopause [Tesis]. Semarang: Fakultas Kedokteran Universitas Diponegoro; 2001.

7. Pratiwi N. Hubungan high density lipoprotein dengan penurunan fungsi kognitif pada wanita post menopause [Skripsi]. Surakarta: Fakultas Ilmu Kesehatan Universitas Muhammadiyah; 2010.

8. Rahajoe AU. Penyakit jantung pada perempuan. Jurnal Kardiologi Indonesia. 2007;28:169-70.

9. Swapnali RK, Kisan R, Jayaprakash Murthy DS. Effect of menopause on lipid profile and apolipoproteins. $\mathrm{Al}$ Ameen J Med Sci. 2011;4:221-8.

10. Khairani R, Sumiera M. Profil lipid pada penduduk lanjut usia di Jakarta. Universa Medicina. 2005;24:175-83.

11. Shende SS, Iyer CM, Mahajan VV, Chakole S, Kute P, Sonare A. Effect of duration on lipid profile status in post-menopausal women. The Health Agenda. 2014;2:90-94.

12. Bade G, Shah S, Nahar P, Vaidya $S$. Effect of menopause on lipid profile in relation to body mass index. Chronicles of Young Scientists.
2014;5:20-4.

13. Ifueko OD. Serum lipid profile of postmenopausal women in Sapele, Delta State, Nigeria. Journal of Medicine and Medical Research. 2013;1:9-13.

14. Kanwar G, Kirad S, Chawala L, Jain N. A comparative study of serum lipid profile between premenopausal and postmenopausal women in Kota, Rajasthan, India. Impact Journals. 2014;2:61-6.

15. Kim CJ, Kim TH, Ryu WS, Ryoo UH. Influence of menopause on high density lipoprotein-cholesterol and lipids. J Korean Med Sci. 2000;15:380-6.

16. Kulkarni MD, Kammar KF. Lipid profile in postmenopausal women of Hubli city. J Pub Health Med Res. 2014;2:25-28.

17. Mesalic L, Tupkovic E, Kendic S, Balic D. Correlation between hormonal and lipid status in women in menopause. Bosnian Journal of Basic Medical Sciences. 2008;8:188-92.

18. Woodard GA, Brooks MM, Mitchel EB, Mackey RH, Matthews KA, Tyrrell KS. Lipids, menopause, and early atherosclerosis in Study of Women's Health Across the Nation Heart women. The Journal of the North American Menopause Society. 2010;18:1-8.

19. Derby AC. Cardiovascular pathophysiology. In: Lobo RA, Kelsey J, Marcus $\mathrm{R}$, editors. Menopause biology and pathobiology. San Diego: Academic Press, 2000; p. 229-44.

20. Arooj B, Khurshid R, Hashmat N, Saleem M. Association of hypertension with ApoE4 and lipid profile in women with different menopausal status. Pak J Physiol. 2013;9:29-31.

21. Swarnalatha PK, Ebrahim NKC. A correlative study of estrogen and lipid profile in pre-menopausal and postmenopausal women. International Journal of Biomedical and Advance Research. 2012;3:818-22. 